Volume 16, Number 1, Juni 2019

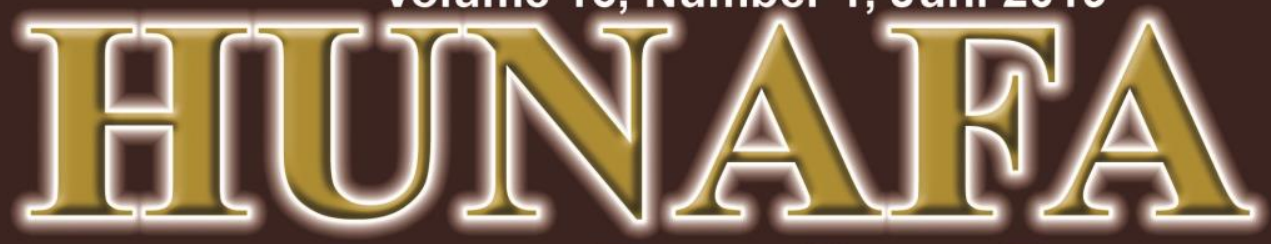

Jurimal Stradial Islamilka

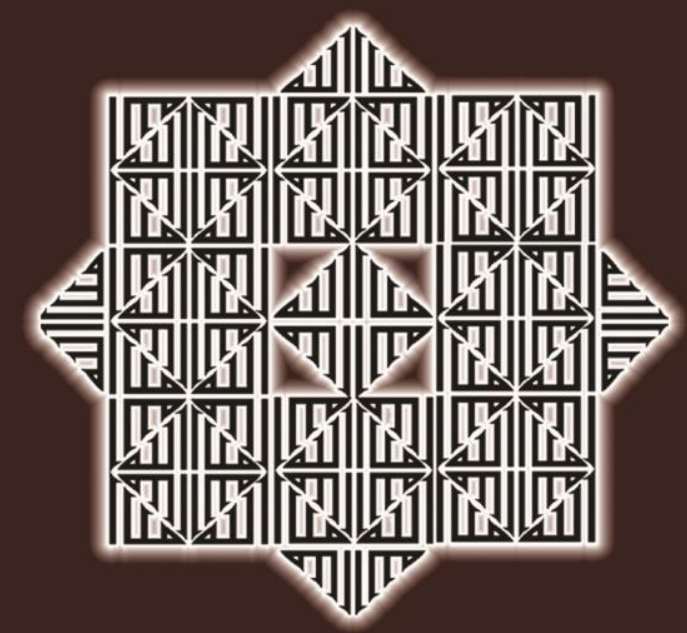

ALKHAIRAAT POLITICAL CHARISMA Syamsuri

IRAN REVOLUTION, ECONOMIC STRUGGLE AND INDEPENDENCE UNDER PRESSURE Meirizon Alizar Ali

\author{
MARKETING PERFORMANCE DETERMINANT \\ OF HALAL PRODUCTS IN INDONESIA \\ Confirmatory Factor Analysis Approach \\ Aan Nasrullah
}

State lnstitute for lsiamic Studies (ILAIN) Palu central Sulawesi

\begin{tabular}{|c|c|c|c|c|c|}
\hline $\begin{array}{c}\text { HUNAFA } \\
\text { JSI }\end{array}$ & $\begin{array}{c}\text { Volume } \\
16\end{array}$ & $\begin{array}{c}\text { Number } \\
1\end{array}$ & $\begin{array}{c}\text { Page } \\
1-153\end{array}$ & $\begin{array}{c}\text { Palu } \\
\text { Juni } 2019\end{array}$ & $\begin{array}{c}\text { ISSN } \\
\text { 141-125X }\end{array}$ \\
\hline
\end{tabular}




\section{HUNAFA}

Jurnal Studia Islamika

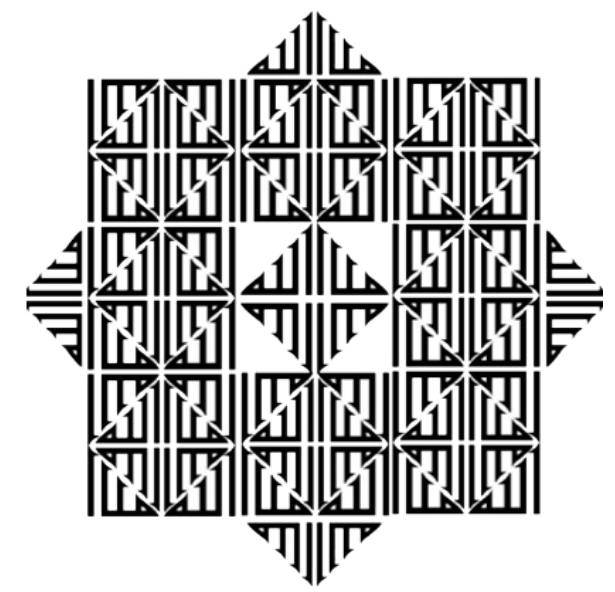

Published by:

State Islamic Institute (IAIN) Palu

Central Sulawesi 


\section{HUNAFA}

Jurnal Studia Islamika

HUNAFA: Jurnal Studia Islamika is an Islamic studies journal dedicated to publishing scholarly articles on all aspects of Islam and the Muslim peoples and religious studies. Available in print and online and published twice a year, the journal aims to become one of the leading platforms in Indonesia for new findings and discussions of all fields of Islamic studies. This journal invites scholars, researchers, and students to contribute the result of their studies and researches in the areas related to Islam and Muslim society which covers textual and fieldwork investigation with various perspectives of law, education, quranic studies, economiy, philosophy, mysticism, theology, sociology, and others.

\section{CAll rights reserved}

No part of this publication may be reproduced in any form without written permission from HUNAFA, to whom all requests to reproduce copyright material should be directed. HUNAFA grants authorization for individuals to photocopy copyright material for private research use. This authorization does not extend to any other kind of copying, by any means, in any form, and for any purposes other than private research.

\section{Open Acces Journal Information}

The journal provides immediate open access to its content on the principle that making research freely available to the public supports a greater global exchange of knowledge. The journal offers full access contents at http://jurnalhunafa.org.

\section{Printed Journal Subscription Information}

Institution Rp 100.000,00 /issue; Rp 1.100.000,00/year

Individual: Rp. 60.000,00/issue; Rp. 600.000,00/year

Outside Indonesia (individual or institution) \$60/month; \$600/year

For detail information of printed journal subscription, feel free to contact the journal manager at hunafajournal@gmail.com.

\section{Mailing Address}

HUNAFA: Jurnals Studia Islamika

Lembaga Penelitian dan Pengabdian Masyarakat (LP2M) IAIN Palu 
Jl. Diponegoro No. 23 Palu, Sulawesi Tengah 94221 Indonesia

Phone: +62-451-460798; Fax: +62-451-460165

E-mail: jurnalhunafa@yahoo.com; hunafajournal@gmail.com

Website: www.jurnalhunafa.org

HUNAFA

Jurnal Studia Islamika

\section{EDITOR-IN-CHIEF}

Nurdin, Institut Agama Islam Negeri Palu, Indonesia

\section{EDITORIAL BOARD}

Sagaf S. Pettalongi, Institut Agama Islam Negeri Palu, Indonesia

Rusli, Institut Agama Islam Negeri Palu, Indonesia

Tulus Suryanto, Universitas Islam Negeri Raden Intan Lampung, Indonesia

Ade Yeti Nuryantini, Universitas Islam Negeri Sunan Gunung Djati, Indonesia

Toto Suharto, Institut Agama Islam Negeri Sukoharjo, Indonesia

Reza Fahmi, Universitas Islam Negeri Imam Bonjol Padang, Indonesia

Mohamad Abdalla, University of South Australia, Australia

Cucuk Wawan Budiyanto, Universitas Sebelas Maret, Indonesia

Kevin W. Fogg, University of Oxford, United Kingdom

Al Makin, Universitas Islam Negeri Sunan Kalijaga Yogyakarta, Indonesia

Miftachul Huda, Universiti Teknologi Malaysia, Malaysia

Hendri Tanjung, Ibn Khaldun University Bogor, Indonesia

Muhammed Modassir Ali, Hamad bin Khalifa Universty, Qatar

Hamid Fahmi Zarkasyi, Universitas Darussalam Gontor, Indonesia 


\section{MANAGING EDITOR}

Mohammad Nur Ahsan, Institut Agama Islam Negeri Palu, Indonesia

\section{COVER DESIGN}

Lukman Latif 


\section{HUNAFA \\ Jurnal Studia Islamika}

\section{Contents}

Editorial

vi-vii

AL-KHAIRAAT POLITICAL KHARISMA

$1-18$

Syamsuri

BANGRENG AS A MEANS OF SPREADING ISLAM

Melyan Sofian, Cece Sobarna, Reiza D. Deinaputra, Deni Hermawan

FOREIGN LANGUAGE TEACHING AND INFORMATION COMMUNICATION TECHNOLOGY: IS THERE OPPORTUNITY FOR QURANIC LANGUAGE TEACHERS?

Nuril Mufidah, Abduganiy Abimbola Abdussalam, Aliy Abdulwahid Adebisi

IRAN REVOLUTION, ECONOMIC STRUGGLE AND INDEPENDENCE UNDER THE PRESSURE

Meirozon AlizarAli 
Umi Salamah

MAHRAM IMPLICATIONS IN WOMEN'S TRAVEL

$88-110$

Maulidah Tri Utami

MARKETING PERFORMANCE DETERMINANT

OF HALAL PRODUCTS IN INDONESIA:

Confirmatory Factor Analysis Approach

Aan Nasrullah

RELATIONS BETWEEN MOSQUE AND

$142-153$

SOCIAL HISTORY OF ISLAMIC EDUCATION

Anna Triayudha, Rateh Ninik Pramitasary, Hermansyah Akbar Anas, Choirul Mahfud 


\section{Editorial Preface}

Nurdin Nurdin, Institut Agama Islam Negeri (IAIN) Palu

This issue (Vol. 16 issues 1) of Hunafa: Jurnal Studia Islamika offers eight articles covering topics of Islamic studies. Various issues relating to Islamic studies are presented interestingly to contribute to the body of knowledge and practices. Academia and practitioners in Islamic studies may gain insight from reading these articles.

The first article is titled "Al-Khairaat Political Kharisma" by Syamsuri Syamsuri from Department of Dakwah, Faculty of Ushuluddin, Adab, and Dakwah, Institut Agama Islam Negeri Palu. This paper discusses the roles of Al-Khairaat in politics arena within local and national level. Several political parties have come to the Alkhairaat organization to recruit political cadres in the face of general election events.Alkahiraat's political charisma in the frame of political communication includes the participation, consolidation, and partnership of Alkhairaat politicians who spread in various political parties to win the election contestation.

The second article in the issue is titled "Bangreng as a Means of Spreading Islam" by Maylan Sofian, Cece Sobarna, Reiza D. Dienaputra, and Deni Hermawan from STKIP Sebelas April Sumedang. This paper describe Bangreng culture which was originally an example used by the Sumedang community as a medium to express gratitude for everything that Allah SWT gave to humans. But the function of art as a ritual began to shift into art as entertainment. This Bangreng art is an art that is very interesting to study because there are only a few different functions. This change does not change the name of the show. With this description, it needs to be isolated, that is, the community does not lose identity. The aim is that the public knows the function of the nation in the spread of Islam.

The third article is titled "Determinants of Halal Product Marketing Performance In Indonesia: Confirmatory Factor Analysis Approach" by Aan Nasrullah. This paper discussed the five variables that contribute to halal product marketing which are product competition, HR marketing performance, infrastructure, amount of distribution cost, and market competition.

The fourth article is titled "Foreign Language Teaching and Information Communication Technology: Is There Opportunity for Quranic Language Teachers?"by Nuril Mufidah, Abdulganiy Abimbola Abdussalam, Aliy Abdulwahid Adebisi from UIN Maulana Malik Ibrahim Malang and University of Ilorin, Ilorin, Nigeria. The article discuses the use of ICT in learning of Arabic. The subjects of the study were students of Arabic Language Education at UIN Maulana Malik Ibrahim Malang Indonesia 2018 academic year and students and Department of Arabic, Faculty of Arts University of Ilorin, Nigeria. The findings of the research are that ICT if adequately harnessed and utilized will go a long way in enhancing the quality of teaching of Arabic, as it was established to teaching other languages of the world.

The fifth article is by Meirizon Alizar Ali dari UIN Imam Bonjol. The article is titled "Iran Revolution, Economic Struggle and Independence under the Pressure" The article discusses 
Iran economy situation after experiencing various kinds of changes in economic policy and facing various kinds of situations Iran succeeded in developing the economy without changing the basics of Islamic shari'ah principles and revolution.

The sixth article is titled "Kaisa Method in Intelligence Multiple Perspective" by Umi Salamah from PGMI, STAI Ma'had 'Aly Al-Hikam, Malang. The article analyzed memorizing the Qur'an using the Kaisa method in the perspective of multiple intelligence. The Kaisa method is a way of memorizing the Qur'an which is oriented to memorization and understanding of the verses of the Qur'an along with their meanings through movements or kinesthetic which are adapted to the meaning of each verse so as to make it easy to understand and remember every verse of the Qur'an given.

The seventh article is titled "Mahram Implications in Women's Travel" by Maulidah Tri Utami from Faculty UshuluddinAdab and Humaniora, IAIN Salatiga. The article discusses mahram as well as a culture of the manner in which a woman is going out of her home or is drawn. From the various resources available this article determine when a woman can compete without mahram.that is how Islam respects and cares for a woman so much that it also notices when a woman is about to travel. Not just one woman, but all Muslim have a rule if a Muslim is to compete for a long time. So, when to reply a Muslim must meet or finish what he needs before taking a sauna.

The last article is titled "Relations Between Mosque And Social History of Islamic Education" by Choirul Mahfud Anna Triayudha, Rateh Ninik Pramitasary, and Hermansyah Akbar Anas from Institut Teknologi Sepuluh Nopember, Surabaya and Pascasarjana Universitas Muhammadiyah Sidoarjo. The article describe the early period of Islamic education, the Prophet provided exemplary by building and empowering mosques. The example of the Prophet continued with the Caliphs afterwards until the present era. The mosque was built by the Prophet from the Al Haram mosque located in Makkah, Quba Mosque located in Quba, Nabawi mosque located in Medina and so on. The role and function of the mosque at that time was as a place of prayer, a place of prayer, a place for discussion or deliberation, a meeting place to develop a war strategy and others related to the problems and needs of Muslims. From time to time, the role or function of the mosque has changed slightly. In essence, mosques are currently influencing the development of the social history of Islamic education in Indonesia.

I hope the articles presented in this issue add further empirical evidence to the growing body of research that examines various fields from Islam perspectives. The articles could trigger other research to study other field of study with Islam perspectives Islamic institutions in Indonesia.

Nurdin Nurdin

Editor-in-Chief

HUNAFA: Jurnal Studia Islamika

XVI, 1 


\title{
KAISA METHOD IN INTELLIGENCE MULTIPLE PERSPECTIVE
}

Umi Salamah ${ }^{1}$

1PGMI, STAI Ma'had ‘Aly Al-Hikam, Malang, umisalamah393@gmail.com

\begin{abstract}
Memorizing the Qur'an usually uses conventional methods (drill, listen, imitate) and is less attractive when applied to children. The purpose of this study was to analyze memorizing the Qur'an using the Kaisa method in the perspective of multiple intelligence. The Kaisa method is a way of memorizing the Qur'an which is oriented to memorization and understanding of the verses of the Qur'an along with their meanings through movements or kinesthetic which are adapted to the meaning of each verse so as to make it easy to understand and remember every verse of the Qur'an given. This research method is descriptive qualitative, data collection is through observation, interviews, and documentation. The research results obtained that memorizing the Qur'an using the Kaisa method is able to accommodate multiple intelligences (multiple intelligence)
\end{abstract}

Keywords: memorizing the Qur'an, the Kaisa method, multiple intelligence

\begin{abstract}
Abstrak. Menghafal Al-Qur'an biasanya menggunakan metode konvensional (drill, mendengarkan, menirukan) dan kurang menarik jika diterapkan pada anak-anak. Tujuan penelitian ini untuk menganalisis menghafal Al-Qur'an menggunakan metode kaisa dalam perspektif multiple intelegence. Metode kaisa adalah cara menghafal al-Qur'an yang berorientasi pada hafalan dan pemahaman ayat al-Qur'an beserta artinya melalui gerakan atau kinestetik yang disesuaikan dengan arti setiap ayat sehingga memberikan kemudahan untuk memahami dan mengingat setiap ayat Al-Qur'an yang diberikan. Metode penelitian ini adalah deskriptif kualitatif, pengumpulan datanya melalui observasi, wawancara, dan dokumentasi. Hasil penelitian diperoleh bahwa menghafal Al-Qur'an menggunakan metode Kaisa mampu mengakomodir beberapa kecerdasan (multiple intelligence)
\end{abstract}

Kata Kunci: Menghafal Al-Qur'an, Metode Kaisa, multiple intelligence

DOI: $10.24239 /$ jsi.v16i1.529.80-89 


\section{Introduction}

Islam is a revelation that was revealed by Allah SWT to His Messenger to be conveyed to all mankind everywhere and throughout time which regulates all human life and livelihoods in various relationships, both human relations with God, human relations with fellow humans, and human relations with natural. Sourced from the Holy Qur'an as a complement to previous Allah's revelations, since humans were presented on earth, which is complemented and explained by the Sunnah of the Prophet Muhammad.

Al-Qur'an as a life guide and is obligatory for Muslims to learn and apply it in life. So important to study the Qur'an, the first verse revealed reads iqro'(read). If interpreted in depth, this verse is an order to not only be a command to read, but really reflected in thoughts, words, and deeds.

Introducing the Qur'an early will be more quickly attached and not easily lost. Because at the age of children, the brain's ability to absorb information is still very good. It would be very good if children were introduced to the Qur'an first before other knowledge.

Growing love for the Qur'an cannot be done instantly and in a short time, it takes a process to get to know it then to learn and apply it in life. In order to foster curiosity in studying the Qur'an, it takes a sense of love or interest to learn it. One form of love for the Qur'an is to memorize and understand its meaning and keep it memorized.

Today the awareness of parents to equip children about religion, especially in reciting the Qur'an, makes many educational institutions welcome this intention. Many madrassas / schools, madrasas diniyah, make the memorization program a superior program. Many methods are applied so that the memorizing process can be fast and easy. 
Some methods offered include tabarok, Hanifida, Al-Barqy, drill methods, and so on. The purpose of applying these methods is to simplify the process of memorizing the Qur'an. And each method must have its own advantages and disadvantages.

Teaching Al-Qur'an memorization to children is good, but it would be nice if you keep paying attention to the child's development. The world of children is the world of play, we must not eliminate nature. So that the activities must be adapted to the needs and characteristics of the child.

The age of children is still short in concentration, children will be bored if asked to sit quietly and listen. In addition to listening, children also need visuals and motion to make it easy to learn and understand things. This can also be applied in memorizing the Qur'an.

Kaisa method is very suitable to be applied in learning to memorize the Qur'an in children. This method combines the correct pronunciation, movement, and meaning. So that in one activity has combined several aspects of intelligence. With the movement the child becomes enthusiastic to learn and memorize the Qur'an, each movement according to the meaning of the verse being recited.

\section{The Kaisa Method in Memorizing the Qur'an}

Method is a systemic way of working to facilitate the implementation of an activity in order to achieve the specified goals. Based on this understanding, it can be interpreted that the method is the method used to achieve the goal. So, the method used must be in accordance with the objectives to be achieved.

Memorizing the Qur'an is a process that is not easy and must be continuous. Teaching memorizing the Qur'an requires an appropriate method so that children are easy to memorize and are interested in learning it. One method that is suitable for children in memorizing the Qur'an is the Kaisa method. 
The Kaisa method is a way of memorizing the Qur'an which is oriented towards memorizing and understanding the verses of the Qur'an along with their meaning through movement or kinesthetic which is adapted to the meaning of each verse so as to make it easy for children to understand and remember every verse of the Qur'an which is given. The Kaisa method is one of the many methods of memorizing the Qur'an, but the strength of the Kaisa method lies in the approach in which children become relaxed when memorizing, and still prioritize tajwid.

This method is suitable for children because the concentration range of the child is still relatively short, with the child's movement not to sit quietly listening but while moving according to the meaning of the verse being recited. It also adds to the vocabulary and movement of the child. There are several intelligences that are honed in the Kaisa method, linguistic intelligence, kinesthetic intelligence, audiovisual intelligence, and inter-personal intelligence. This method is suitable for kinesthetic children, whose learning style prefers physical activity, trains intrapersonal children to socialize, and helps audio-visual children to memorize more easily because learning by listening and seeing

The following are the learning steps to memorize the Kaisa method:

a. The teacher gives greetings

b. Prepare or give instructions to the students to prepare the teaching and learning process.

c. Presence of the presence of santri (students)

d. Read basmalah and prayer before studying

e. Muroja'ah or repeat memorization

f. Additional memorization by reading verse words in movement / kinesthetic

g. Explain the law of recitation and its meaning / interpretation 
h. Santri recite the verse repeatedly until the verse is memorized

i. One by one the santri recite the verse according to the law of tajweed and translate it per word

j. The teacher listens to the verses memorized by each santri

$k$. The teacher confirms that there is an error with the law of tajwid and its meaning 1. After the first verse is memorized, the teacher guides the santri to proceed to the next verse with the same treatment

m. Reflect on learning by giving verse-connected games (ie memorizing letters continuously)

n. Closing the study with the prayer of the Qur'an and the prayer of the assembly in congregation.

Combining right and left brain is indeed not easy, but this is interesting for children. In the golden age, children, whose absorption capacity was very good and their curiosity was high, made the application of this method effective. The child does not have to sit quietly listening to the total and repeat reading/drafting. Learning activities with movement, playing, quizzes, and given one-on-one opportunities to practice. The movement corresponds to the meaning, so the child knows the meaning of each verse. For example, said syaithon, the hands above his head while holding up his two index fingers meant the devil. Said Arrahman (Most Gracious), both hands crossed on the chest, said Arrahiim (Most Merciful), both hands placed under the chin, like supporting the chin. When a child forgets the reading, it can call the child's memory with only gestures.

Strengths and weaknesses of the Kaisa method

The advantages of the Kaisa method:

a. Interesting for children because they use movement 
b. Enriches vocabulary and movement in children

c. Combining multiple intelligences

d. Train the right and left brain

e. Children not only memorize but also understand tajwid and its meanings The weakness of the Kaisa method:

a. The process of memorizing takes longer

b. Requires special teacher skills

c. Requires careful planning

\section{Multiple Intelligences}

Gardner classifies eight types of intelligence (Garddner's Multiple Intelligences), namely mathematical logic intelligence, language/verbal intelligence, spatial/visual intelligence, kinesthetic intelligence, musical/rhythmic intelligence, interpersonal intelligence, intrapersonal intelligence and natural intelligence.

\section{Mathematical logic intelligence}

This form of intelligence is among the easiest to standardize and measure. This intelligence is an analytical and scientific mind, and can see it in science experts, computer programmers, accountants, bankers, and of course mathematicians.

2. Language / verbal intelligence

This form of intelligence is expressed by sensitivity to the meaning and sequence of words and the ability to make various uses of language to express and interpret complex meanings.

3. Spatial / visual intelligence

This form of intelligence is generally skilled at producing mental imagination and creating graphical representations, they are able to think three dimensions, capable 
of recreating the visual world. This intelligence can be found in painters, sculptors, computer programmers, designers, architects.

\section{Kinesthetic Intelligence}

This form of intelligence enables the connection between mind and body which is needed to succeed in activities such as dancing, exercise, martial arts, playing theater.

\section{Musical / rhythmic intelligence}

This form of intelligence listens to music patterns and is rhythmic in nature and can then produce them. This form of intelligence is very pleasant, because music has the capacity to change our consciousness, eliminate stress and improve brain function.

6. Interpersonal intelligence

This form of intelligence is usually those who are good at reading moods, temperaments, motivations and other people's intentions. Those with this intelligence have negotiation skills and provide feedback or evaluation.

\section{Intrapersonal intelligence}

This form of intelligence is the ability to understand and articulate the deepest workings of character and personality.

8. Natural intelligence

This form of intelligence can be seen as a component of "value" added to it. Natural intelligence is intelligence that guides ourselves to become whole human beings, able to adapt to nature.

\section{The Kaisa Method in the Multiple Intelligence Perspective}

The Kaisa method is very interesting for children, because this method combines verbal, mathematical logic, linguistics, kinesthetic, visual, intra-personal, and so on. With this method the child can memorize and understand the meaning at 
the same time, without putting aside the words and tajwid. On the sidelines of memorizing also explained asbabun nuzul the memorized letter was revealed. Children can memorize, add vocabulary and movements, and increase knowledge about the cause of the letter being revealed in the Qur'an.

Specifically the Kaisa method is examined in the perspective of multiple intelligence explained in the table.1

Table 1

\begin{tabular}{|l|l|l|l|}
\hline No. & \multicolumn{1}{|c|}{ Elements of activity } & \multicolumn{1}{|c|}{ Form activity } & \multicolumn{1}{|c|}{ Intelligence } \\
\hline & Learning & Classical & Interpersonal \\
\hline & Learning methods & Private & Intrapersonal \\
\hline & Demonstration & Kinesthetic \\
\hline fingers & $\begin{array}{l}\text { Give examples of } \\
\text { movements }\end{array}$ & $\begin{array}{l}\text { Linguistic } \\
\text { mathematics }\end{array}$ \\
\hline & & $\begin{array}{l}\text { Break time is } \\
\text { listened to murotal }\end{array}$ & Musical \\
\hline & $\begin{array}{l}\text { Children are } \\
\text { invited to study } \\
\text { outdoors so they } \\
\text { don't get bored }\end{array}$ & Natural \\
\hline
\end{tabular}




\begin{tabular}{|l|l|l|l|}
\hline & $\begin{array}{l}\text { Explain } \\
\text { movements with } \\
\text { their meanings }\end{array}$ & \\
\hline
\end{tabular}

The Kaisa method is a method that facilitates all intelligence. When classical learning, making children who are interpersonal feel comfortable because they can interact with their friends. Likewise intrapersonal children can practice to socialize with their friends. During private learning, intrapersonal children can learn comfortably. Each teaches a new vocabulary, the teacher demonstrates (kinesthetic intelligence) every movement while uttering the lafadz and its meaning (linguistics), this is done many times until the children are able to imitate (visual). Then each child is given the opportunity to try one by one. The teacher mentions how many verses and points with the finger of what verse is being read, this is logical mathematical intelligence. On the sidelines of the rest of the children listen murotal (musical), and occasionally children are invited to study outside / the outdoors so as not to get bored (natural). After the learning is finished, the teacher writes in the contact book about the letter and what verse is referred to that day, then gives a note about the child's development.

\section{Conclusion}

Based on the discussion above, it can be concluded that the Kaisa Method in memorizing the Qur'an is reviewed from the perspective of multiple intelligences, it can be seen that 8 intelligences have been well internalized. Kaisa method has applied the Al Qur'an learning system and method based on multiple intelligences.

\section{Refence}

Bersama Islam.Lima bersaudara ini Hafal Quran dengan Metode Unik

Cox, Richard. "Representation Construction, Externalised Cognition and Individual Differences." Learning and Instruction 9, no. 4 (1999): 343-363. 
http://digilib.iainkendari.ac.id/786/3/BAB\%20II.pdf

https://kbbi.kemdikbud.go.id/entri/metode

Kelly, Declan, and Brendan Tangney. "Incorporating Learning Characteristics into an Intelligent Tutor." In Intelligent Tutoring Systems, edited by Stefano A. Cerri, Guy Gouardères and Fàbio Paraguaçu, 729-738. (Berlin, Heidelberg: Springer Berlin Heidelberg, 2002).

Mudzakir A. Pengantar Studi Islam. (Semarang: Wahid Hasyim University Press, 2014)

Nurdin, Nurdin. "Segregasi Dalam Pengajaran Dan Penguasaan Bahasa." MUSAWA 1, no. 1 (2009): 23-41.

Rauscher, Frances H., Gordon L. Shaw, and Katherine N. Ky. "Listening to Mozart Enhances Spatial-Temporal Reasoning: Towards a Neurophysiological Basis." Neuroscience Letters 185, no. 1 (1995): 44-47.

Smith, Wilfred Cantwell. "The True Meaning of Scripture: An Empirical Historian's Nonreductionist Interpretation of the Qur'an." International Journal of Middle East Studies 11, no. 4 (1980): 487-505.

Snyder, Rebecca Finley. "The Relationship between Learning Styles/Multiple Intelligences and Academic Achievement of High School Students." The High School Journal 83, no. 2 (1999): 11-20.

www.bersamaislam.com 